Review

\title{
Nonsteroidal Anti-Inflammatory Drugs (NSAIDs): Progress in Small Molecule Drug Development
}

\author{
Praveen P. N. Rao *, Saad N. Kabir and Tarek Mohamed \\ School of Pharmacy, Health Sciences Campus, University of Waterloo, 200 University Avenue W. \\ Waterloo, ON, N2L 3G1 Canada
}

* Author to whom correspondence should be addressed; Email: praopera@uwaterloo.ca; Tel.: +1-519-888-4567, ext: 21317; Fax: +1-519-888-7910

Received: 01 April 2010; in revised form: 22 April 2010 / Accepted: 12 May 2010 /

Published: 14 May 2010

\begin{abstract}
Ever since the discovery of aspirin, small molecule therapeutics have been widely prescribed to treat inflammation and pain. Aspirin and several small molecule NSAIDs are known to inhibit the enzymes cyclooxygenase-1 (COX-1) and -2 (COX-2). Despite the success of NSAIDs to treat inflammatory disorders, the development of a clinically useful small molecule NSAIDs with decreased side effect profiles is an ongoing effort. The recent discovery and development of selective COX-2 inhibitors was a step toward this direction. Emerging trends are represented by the progress in the development of hybrid agents such as nitric oxide donor-NSAIDs (NO-NSAIDs) and dual COX/lipoxygenase (LOX) inhibitors. This review focuses on the recent advances in the rational design of small molecule NSAIDs in therapy.
\end{abstract}

Keywords: Small molecules; NSAIDs; Lp-PLA $;$; mPGES-1; TNF- $\alpha$

\section{Introduction}

The history of treating fever, pain and inflammation is a fascinating tale of human adventure that goes back centuries [1]. Since the discovery and isolation of salicin from willow bark in the early 18th century to the development of selective COX-2 inhibitors in the 1990s, small molecule therapies to treat fever, pain and inflammation have evolved [1,2]. Traditional NSAIDs such as aspirin (1), ibuprofen (2) and diclofenac (3) that exhibit nonselective COX inhibition represent some of the most widely prescribed NSAIDs to relieve short term fever, pain and inflammation $[3,4]$. The characteristic 
feature of these traditional nonselective COX inhibitor NSAIDs was the presence of a carboxylic acid $(\mathrm{COOH})$ functional group. In the early 1990s the second isoform of COX was discovered, providing a novel target to develop anti-inflammatory agents with superior safety profiles compared to traditional NSAIDs [5,6]. Consequently, selective COX-2 inhibitors (coxibs) based on a diarylheterocyclic ring template as in celecoxib (4) and rofecoxib (5) were developed [7, 8].

Figure 1. Chemical structures of some nonselective and selective COX inhibitors.<smiles>CC(=O)Oc1ccccc1C(=O)O</smiles>

Aspirin (1)<smiles>CC(C)Cc1ccc(C(C)C(=O)O)cc1</smiles>

Ibuprofen (2)<smiles>O=C(O)Cc1ccccc1Nc1c(Cl)cccc1Cl</smiles>

Diclofenac (3)
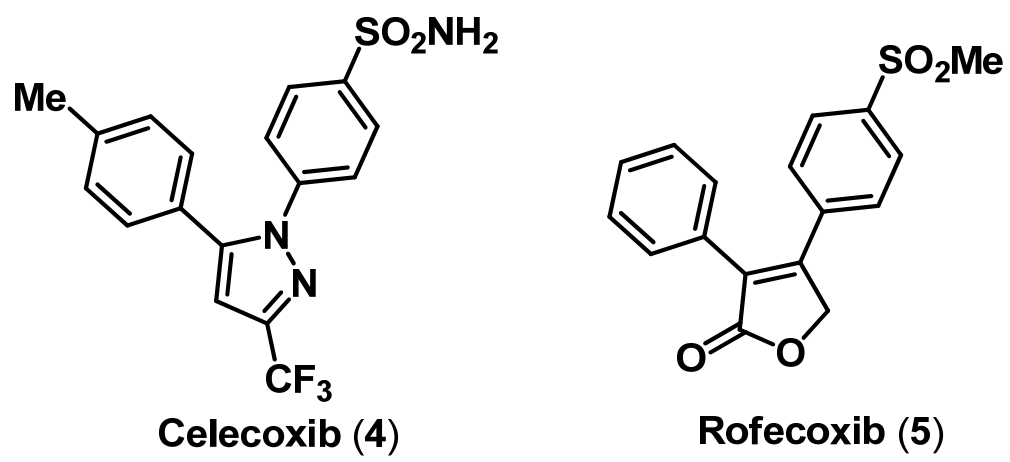

Rofecoxib (5)

These agents were characterized by the presence of a para-sulfonamide $\left(\mathrm{SO}_{2} \mathrm{NH}_{2}\right)$ or a paramethanesulfonyl $\left(\mathrm{SO}_{2} \mathrm{Me}\right)$ pharmacophore present on one of the aryl rings. Crystal structure studies supported the hypothesis that the $p-\mathrm{SO}_{2} \mathrm{NH}_{2}$ or $p-\mathrm{SO}_{2} \mathrm{Me}$ pharmacophore was conferring COX-2 selectivity by orienting in a secondary pocket accessible only in the COX-2 active site [9,10]. The initial euphoria surrounding the selective COX-2 inhibitors, was short lived as studies indicated serious risks of cardiovascular complications in susceptible population during therapy [11,12]. Therefore, developing novel orally active small molecule anti-inflammatory agents with superior safety profile presents a significant challenge. The inflammatory pathway is a complex event involving multiple effectors (Figure 2). Inflammatory mediators such as prostaglandins (PGs), leukotrienes (LTs) and tumor necrosis factor-alpha (TNF- $\alpha$ ) are implicated in a wide variety of diseases such as rheumatoid arthritis (RA), osteoarthritis (OA), asthma, atherosclerosis, different types of cancers and diseases of the central nervous system [13-22]. Traditional NSAIDs targeted COX isozymes, whereas later studies investigated nitric oxide (NO) donating NSAIDs (NO-NSAIDs), dual COX/LOX inhibitors, leukotriene receptor antagonists and selective COX-2 inhibitors in an effort to develop antiinflammatory agents with superior safety profile [5,15,23-25]. Emerging small molecule targets includes phospholipases $\left(\mathrm{PLA}_{2}\right)$, microsomal prostaglandin $\mathrm{E}_{2}$ synthase (mPGES-1) and inhibition of TNF- $\alpha$. This review will focus on the recent drug discovery efforts toward developing novel small molecule ring templates as NO-NSAIDs, selective COX-2, dual COX/LOX, lipoprotein-PLA 2 (LpPLA 2 ), mPGES-1 and TNF- $\alpha$ inhibitors. 
Figure 2. A simplified diagram of the inflammatory pathway and its mediators.

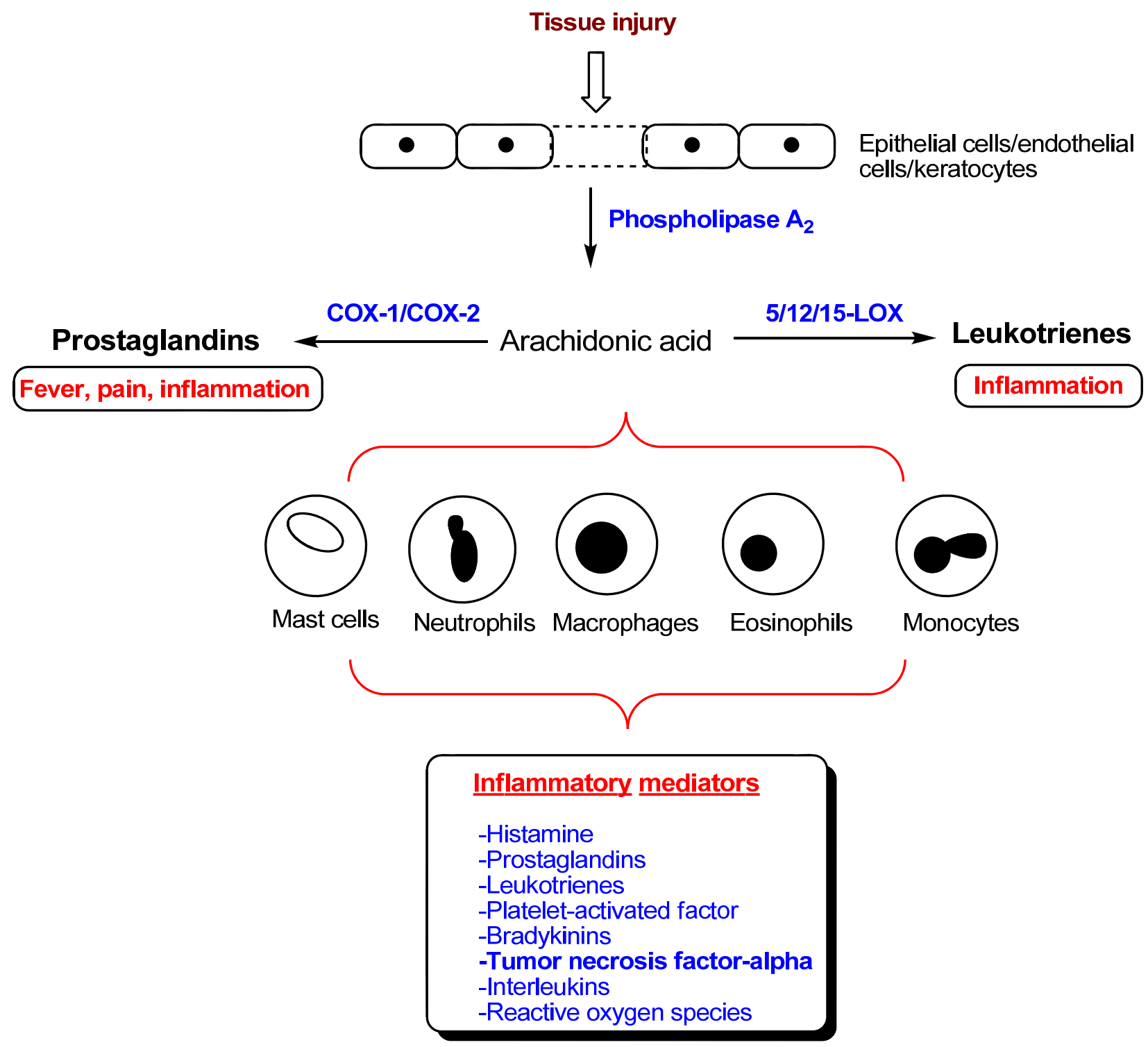

\section{NO-NSAIDs}

The concept of developing hybrid NO-NSAIDs was primarily conceived to decrease the gastrointestinal (GI) toxicities observed with traditional NSAID use. In the GI tract NO is known to exert its protective role by increasing the mucous secretion, mucosal blood flow and inhibition of neutrophil aggregation [24]. In addition, the recent controversy surrounding the cardiovascular side effects of selective COX-2 inhibitors, further supports the need to develop clinically useful NONSAIDs since NO is also known to exhibit beneficial effects on the cardiovascular system by inhibiting platelet aggregation and adhesion [11,26]. Accordingly, several studies focused on developing NO-NSAIDs based on the aspirin, naproxen and diclofenac ring templates. These agents contain organic nitrates or nitrosothiols as the NO-donor moiety [24,27,28].

Diazeniumdiolates (NONOates) represent a unique structural moiety that can be incorporated to develop NO-donating agents [29]. Recently, Knaus and coworkers described the design and synthesis 
of hybrid aspirin, ibuprofen and indomethacin derivatives coupled to diazeniumdiolates as novel NOdonating prodrugs.

Figure 3. Chemical structures of some representative NO-donor anti-inflammatory agents.<smiles>COc1ccc2c(c1)c(CC(=O)OCO/N=[N+](/[O-])N(C)C)c(C)n2C(=O)c1ccc(Cl)cc1</smiles>

(6)<smiles>COc1ccc(-c2c(Cl)ncn2-c2ccc(S(N)(=O)=O)cc2)cc1F</smiles>

(8)<smiles>CCN(CC)C(=O)Cc1c(C)n(C(=O)c2ccc(Cl)cc2)c2ccc(OC)cc12</smiles>

(10)<smiles></smiles>

$\mathrm{R}=\mathrm{H}, \mathrm{n}=\mathbf{1 - 5}$

$R_{1}=M e, n=1-2$

(12)<smiles>COc1ccc2c(c1)c(CC(=O)OCOC(=O)C1CCCN1[N+](=O)NOCOC(C)=O)c(C)n2C(=O)c1ccc(Cl)cc1</smiles>

(7)<smiles>COc1ccc(-c2c(Cl)ncn2-c2ccc(S(C)(=O)=O)cc2)cc1F</smiles>

(9)<smiles></smiles>

(11)<smiles>CC(=O)Oc1ccccc1C(=O)OCOC(=O)CCC(CO[N+](=O)[O-])O[N+](=O)[O-]</smiles>

(13)

The indomethacin derivative possessing a 1-( $N, N$-dimethylamino)diazen-1-ium-1,2-diolate (6, Figure 3) exhibited potent in vivo anti-inflammatory activity $\left(\mathrm{ED}_{50}=5.9 \mathrm{mg} / \mathrm{kg}\right.$, oral dose) and minimal GI toxicity (ulcer index $=3.0 \pm 0.3$, oral dose) compared to the parent indomethacin (COX-2 $\mathrm{IC}_{50}=5.7 \mu \mathrm{M}$; COX-1 $\left.\mathrm{IC}_{50}=0.10 \mu \mathrm{M}\right)$. In another follow-up study, the indomethacin derivative linked to a 1-(2-carboxypyrrolidin-1-yl)diazen-1-ium-1,2-diolate by a methylene spacer (7) exhibited oral anti-inflammatory activity while exhibiting no GI toxicity $(0.08 \mathrm{mmol} / \mathrm{kg}$, oral dose $)$. The in vitro assay data showed that these NO-donating prodrugs were devoid of COX inhibition [30,31]. 
Gasco and coworkers developed a series of metabolically stable selective COX-2 inhibitor NOdonors (CINODs) based on a 1,5-diarylimidazole ring template [32]. The organic nitrate, nitroxysubstituted alkyloxy groups were incorporated on one of the aryl rings as a NO-donor moiety. The sulfonamide derivative possessing a phenoxyethyl nitrate NO-donor moiety (8) retained COX-2 selectivity $\left(\mathrm{COX}-2 \mathrm{IC}_{50}=29 \mu \mathrm{M}\right.$; COX-1 $\left.\mathrm{IC}_{50}>100 \mu \mathrm{M}\right)$ and exhibited superior vasodilatory properties relative to the parent cimicoxib. The corresponding methanesulfonyl derivative (9) exhibited superior COX-2 selectivity $\left(\mathrm{COX}-2 \mathrm{IC}_{50}=6.9 \mu \mathrm{M}\right.$; COX-1 $\left.\mathrm{IC}_{50}>100 \mu \mathrm{M}\right)$ and vasodilatory properties relative to $\mathbf{8}$. It should be noted that these novel CINODs exhibit decreased COX inhibitory potency relative to the lead selective $\mathrm{COX}-2$ inhibitor cimicoxib $\left(\mathrm{COX}-2 \mathrm{IC}_{50}=0.10 \mu \mathrm{M}\right.$; $\mathrm{COX}-1 \mathrm{IC}_{50}$ $=1.9 \mu \mathrm{M}$ ). Recently, NitroMed Inc. reported a group of indomethacin derivatives as selective COX-2 inhibitors with NO-donating properties [33]. The indomethacin amide derivative possessing an organic

nitrate NO-donor moiety (10, Figure 3 ) exhibited effective in vitro COX-2 selectivity (COX-2 $\mathrm{IC}_{50}=1.2 \mu \mathrm{M}$; COX-1 $\left.\mathrm{IC}_{50}=6.0 \mu \mathrm{M}\right)$ and oral anti-inflammatory activity. The sulfonamide derivative possessing a nitrooxypropyl NO-donor moiety (11) exhibited superior in vitro COX-2 selectivity relative to $\mathbf{1 0}$ and was an equipotent inhibitor of COX-2 with oral anti-inflammatory activity. However, only rats treated with $\mathbf{1 0}$ exhibited increased nitrite and nitrate concentration in plasma indicating its NO-donating property in vivo. In addition, $\mathbf{1 0}$ exhibited an $85 \%$ reduction in gastric lesions when administered orally in a rat model of aspirin-induced rat gastric damage model (dose $=45 \mu \mathrm{mol} / \mathrm{kg})$.

The ever popular agent aspirin continues to be the focus of current research [34-36]. Recent studies have reported novel aspirin and aspirin derivatives possessing organic nitrate NO-donor moiety. In this regard, Gasco and coworkers prepared novel aspirin-like derivatives based on salicylic acid ring template possessing a nitrooxy-acyl NO-donor moiety (12) and aspirin derivatives possessing a (nitrooxyacyloxy)methyl ester NO-donor moiety (13). These agents exhibited effective oral antiinflammatory and vasodilatory properties with reduced GI toxicities [36].

\section{Selective COX-2 Inhibitors}

The adverse cardiovascular events associated with selective COX-2 inhibitors led to a dramatic decline in selective COX-2 inhibitor pipeline. In this regard, Tragara Pharmaceuticals is developing an orally active, selective COX-2 inhibitor $\left(\mathrm{COX}-2 \mathrm{IC}_{50}=0.31 \mu \mathrm{M} ; \mathrm{COX}-1 \quad \mathrm{IC}_{50}=2.2 \mu \mathrm{M}\right)$ to treat different types of neoplasia such as tumors of lung, breast and pancreas [37]. Apricoxib has a 1,2diphenyl template attached to a central 5-membered pyrrole ring along with a para- $\mathrm{SO}_{2} \mathrm{NH}_{2} \mathrm{COX}-2$ pharmacophore (14, Figure 4). In addition, a group of regioisomeric 1,5-diphenylpyrroles possessing a para- $\mathrm{SO}_{2} \mathrm{Me} \mathrm{COX}-2$ pharmacophore were reported as selective COX-2 inhibitors $\left(\mathbf{1 5}, \mathrm{COX}-2 \mathrm{IC}_{50}=\right.$ $2.1 \mu \mathrm{M}$; COX-1 $\mathrm{IC}_{50}=20.4 \mu \mathrm{M} ; 16 \mathrm{COX}-2 \mathrm{IC}_{50}=0.018 \mu \mathrm{M}$; COX-1 $\left.\mathrm{IC}_{50}>100 \mu \mathrm{M}\right)$ that exhibited effective oral anti-inflammatory and analgesic activities. However, these studies did not report the cardiovascular safety of these agents [38-40]. Furthermore, Pfizer scientists reported a group of benzopyran derivatives as selective COX-2 inhibitors [41]. These are structurally different from the diarylheterocyclic class of selective COX-2 inhibitors. A representative compound from this series SC75416 (17) contains a $\mathrm{COOH}$ and $\mathrm{CF}_{3}$ substituent. It is noteworthy that this agent did not contain either a $\mathrm{SO}_{2} \mathrm{NH}_{2}$ or a $\mathrm{SO}_{2} \mathrm{Me} \mathrm{COX}-2$ pharmacophore. Compound 17 exhibited effective oral anti- 
inflammatory activity and similar COX inhibition/selectivity $\left(\mathrm{COX}-2 \mathrm{IC}_{50}=0.25 \mu \mathrm{M}\right.$; COX-1 $\left.\mathrm{IC}_{50}=49.6 \mu \mathrm{M}\right)$ relative to celecoxib.

Figure 4. Chemical structures of some representative selective COX-2 inhibitors.

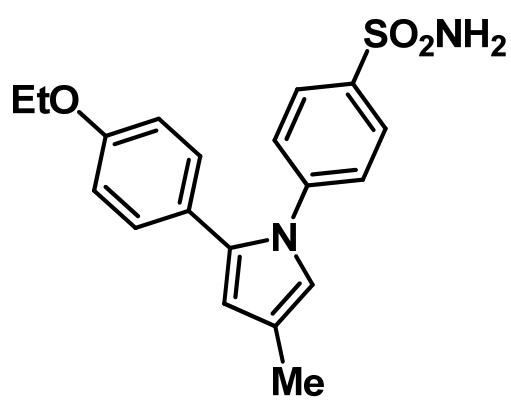

Apricoxib (14)

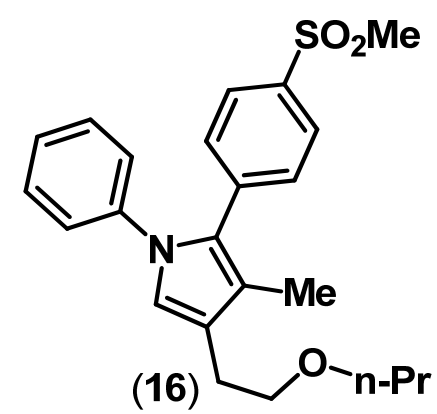

$\underbrace{\mathrm{NHSO}}_{\mathrm{N}}$

(18)

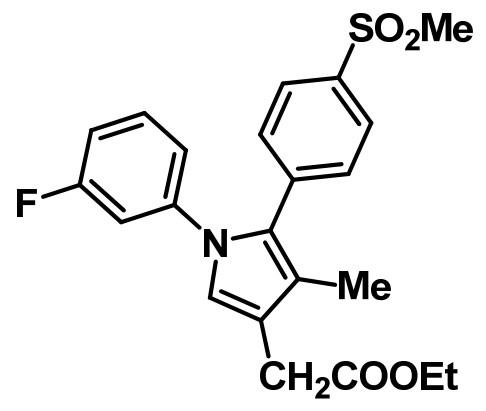

(15)<smiles>CC(C)(C)c1cc2c(cc1Cl)C=C(C(=O)O)[C@H](C(F)(F)F)O2</smiles><smiles>COS(=O)(=O)c1ccc(-c2cc(C(F)(F)F)nc(NCC(C)C)n2)cc1</smiles>

(19)

In another study, Renard and coworkers designed novel nimesulide derivatives as selective COX-2 inhibitors [42]. The alkanesulfonamide $\left(\mathrm{MeSO}_{2} \mathrm{NH}\right)$ in nimesulide was replaced with a trifluoromethanesulfonamide $\left(\mathrm{CF}_{3} \mathrm{SO}_{2} \mathrm{NH}\right)$ moiety and the ether linkage was replaced with a secondary amine bridge. A representative agent 18 (Figure 4) exhibited a good combination of oral antiinflammatory activity and in vitro $\mathrm{COX}-2$ selectivity $\left(\mathrm{COX}-2 \quad \mathrm{IC}_{50}=0.12 \mu \mathrm{M}\right.$; $\mathrm{COX}-1$ $\left.\mathrm{IC}_{50}=0.91 \mu \mathrm{M}\right)$. In 2009, GlaxoSmithKline (GSK) scientists reported the development of a novel series of trifluoromethylpyrimidine based ring scaffolds (19, COX-2 $\mathrm{IC}_{50}=206 \mathrm{nM}$; COX-1 $\left.\mathrm{IC}_{50}=62000 \mathrm{nM}\right)$ as highly potent and selective COX-2 inhibitors [43,44]. Accordingly, several diverse classes of selective COX-2 inhibitors have been reported and a thorough discussion is beyond the scope of this review [45]. It should be noted that COX-1/COX-2 inhibition and selectivity data is highly variable based on the biochemical assay method used. In addition, in vivo antiinflammatory/analgesic activities and side effects (GI, renal and cardiovascular) of NSAIDs are highly 
dose dependent. These factors contribute to the difficulty associated in determining specific COX-1 and COX-2 selectivity ratios for future development.

\section{Dual COX/LOX Inhibitors}

Currently, LOXs are potential targets in the treatment of diseases such as asthma, atherosclerosis, cancer, and a variety of inflammatory conditions [14-16]. It was hypothesized that blocking the arachidonic acid (AA) metabolism via COX inhibition by either traditional NSAIDs or selective COX2 inhibitors could lead to the generation of proinflammatory leukotrienes and lipoxins via the LOX pathway (Figure 2) partly accounting for the side effects seen with traditional NSAIDs and selective COX-2 inhibitors. To counter this, several dual small molecule COX/LOX inhibitors have been reported. Reddy and coworkers reported the development of racemic indolylpyrazoline class of agents as dual COX/LOX inhibitors. One of the examples shown in Figure $5(\mathbf{2 0})$ had a para- $\mathrm{SO}_{2} \mathrm{NH}_{2} \mathrm{COX}-2$ pharmacophore and exhibited dual COX and LOX inhibition $\left(\mathrm{COX}-2 \mathrm{IC}_{50}=3.9 \mu \mathrm{M}, \mathrm{COX}-1 \mathrm{IC}_{50}>\right.$ $100 \mu \mathrm{M}$; 5-LOX IC I0 $_{50}=94 \mu \mathrm{M}, 12-\mathrm{LOX} \mathrm{IC}_{50}=3 \mu \mathrm{M}, 15-\mathrm{LOX} \mathrm{IC}_{50}=36 \mu \mathrm{M}$ ). The levo isomers exhibit superior COX-2 inhibitory potency and selectivity.

Figure 5. Chemical structures of some representative dual COX/LOX inhibitors.<smiles>NS(=O)(=O)c1ccc(N2N=C(C(F)(F)F)CC2c2c[nH]c3c(Cl)cccc23)cc1</smiles>

(20)

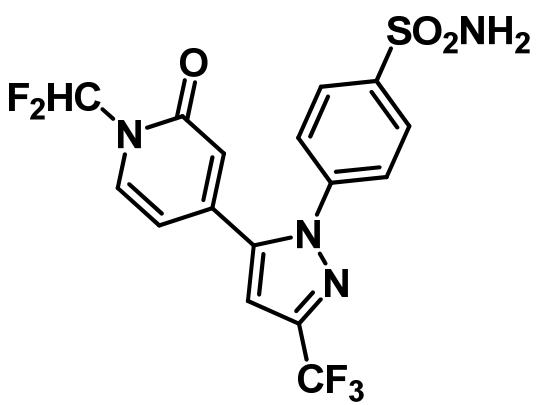

(22)<smiles>O=C1N=C(Nc2nccs2)S/C1=C/c1cccc(Cl)c1</smiles>

(21)<smiles>O=[N+]([O-])c1ccc2c(c1)S(=O)N=S2c1ccc(Br)cc1</smiles>

(23)

However, for this series of compounds, in vivo anti-inflammatory activities were not reported [46]. Furthermore, Lagunin and coworkers recently used structure-based virtual screening to identify suitable ring scaffolds as dual COX/LOX inhibitors [47]. This study revealed that a thiazolidinone ring scaffold could be used to develop novel anti-inflammatory agents. Compound 21 (Figure 5) exhibited weak in vitro COX and soyabean LOX inhibitory potency (COX-2 $\mathrm{IC}_{50}=262 \mu \mathrm{M}, \mathrm{COX}-1 \mathrm{IC}_{50}=125$ $\mu \mathrm{M}$; LOX $\left.\mathrm{IC}_{50}=125.9 \mu \mathrm{M}\right)$. In vivo 21 exhibited good anti-inflammatory activity (44.5\% inhibition, 
dose $=0.01 \mathrm{mmol} / \mathrm{kg}$ ) when administered through intraperitoneal route in animal models. However, oral activity was not reported.

LOX isozymes are non-heme enzymes containing a catalytic ferric iron with a high reduction potential. Studies have indicated that iron chelators such as catechols and hydroxamic acid derivatives are capable of reducing the iron to its inactive state, thereby preventing the conversion of fatty acids to pro-inflammatory lipid mediators [48]. In this regard, Knaus and coworkers developed several hybrid COX/5-LOX inhibitors possessing a novel $N$-difluoromethyl-1,2-dihydropyridine-2-one LOX pharmacophore [49-51]. It was anticipated that the $\mathrm{CONCHF}_{2}$ moiety present in $\mathrm{N}$-difluoromethyl1,2-dihydropyridine-2-one acts as a cyclic hydroxamic acid mimetic by chelating LOX iron. A celecoxib derivative incorporating the $N$-difluoromethyl-1,2-dihydropyridine-2-one LOX pharmacophore (22) exhibited dual COX and 5-LOX inhibition (COX-2 IC $50=0.69 \mu \mathrm{M}, \mathrm{COX}-1 \mathrm{IC}_{50}$ $=13.1 \mu \mathrm{M} ; 5$-LOX IC $\left.\mathrm{IC}_{50}=5.0 \mu \mathrm{M}\right)$ along with oral anti-inflammatory activity $\left(\mathrm{ED}_{50}=27.7 \mathrm{mg} / \mathrm{kg}\right) . \mathrm{In}$ an elegant study, Chern and coworkers applied structure-based virtual screening and discovered a novel benzo[1.3.2] dithiazolium ylide-based ring scaffold as dual COX/5-LOX inhibitors [52]. The lead compound 23 (Figure 5), possessing a dithiazolium ylide 1,1-dioxide exhibited dual COX/5-LOX inhibition (COX-2 $\mathrm{IC}_{50}=1.7 \mu \mathrm{M}$, COX-1 $\mathrm{IC}_{50}=6.7 \mu \mathrm{M}$; 5-LOX $\left.\mathrm{IC}_{50}=1.22 \mu \mathrm{M}\right)$. It was also interesting to note that 23 exhibited TNF- $\alpha$ inhibition $\left(\mathrm{IC}_{50}=0.44 \mu \mathrm{M}\right)$ in a lipopolysaccharide (LPS)induced human acute monocytic leukemia cell line (THP-1) assay. The molecular modeling studies indicated that the $(S)$-enantiomer is potentially responsible for the observed COX-2 selectivity. In vivo anti-inflammatory activity data for these agents have not been reported.

\section{Lp-PLA2 Inhibitors}

The phospholipase $\mathrm{A}_{2}\left(\mathrm{PLA}_{2}\right)$ enzyme catalyzes the release of fatty acids such as AA, a critical ratelimiting step, by acting on membrane phospholipids (Figure 2). The released AA gets converted to various pro-inflammatory mediators such as prostaglandins, leukotrienes and platelet-activating factor (PAF) that are known to play a major role in regulating the vascular tone [53]. The $\mathrm{PLA}_{2}$ is classified into three major subtypes: secretory $\left(\mathrm{sPLA}_{2}\right)$; cytosolic or $\mathrm{Ca}^{2+}$-activated $\left(\mathrm{cPLA}_{2}\right)$; and inducible or $\mathrm{Ca}^{2+}$-independent $\left(\mathrm{iPLA}_{2}\right)$. In this regard, Lp-PLA 2 also known as platelet-activating factor acetylhydrolase (PAF-AH) is a $\mathrm{Ca}^{2+}$-independent $\mathrm{PLA}_{2}$ that is classified as group VIIA PLA 2 . Furthermore, recent studies have indicated that $\mathrm{Lp}-\mathrm{PLA}_{2}$ is closely involved in the onset and progression of atherosclerosis [53-57]. The enzyme Lp-PLA 2 or PAF-AH (EC 3.1.1.47) was first identified from plasma that was known to hydrolyze/inactivate PAF, a phospholipid mediator produced from macrophages, monocytes, platelets and neutrophils involved in inflammatory diseases including atherosclerosis $[58,59]$. In humans, Lp-PLA 2 is primarily produced from leukocytes and macrophages and is associated with circulating macrophages and low-density lipoproteins (LDL). It acts on polar phospholipids in oxidized LDL to form lysophosphatidylcholine and nonesterified phospholipids that are known to have proinflammatory properties by activating and recruiting macrophages/monocytes mediating plaque vulnerability, apoptosis, leading to onset and progression of atheroma [60,61]. These studies suggest that Lp-PLA 2 is a unique biomarker to predict long-term cardiovascular risk [62-64].

The drug discovery of novel small molecule PLA 2 inhibitors is an ongoing effort $[65,66]$. Several indole-based inhibitors of $\mathrm{SPLA}_{2}$ have been developed to treat various inflammatory conditions such as 
pancreatitis, allergic rhinitis, rheumatoid arthritis, gout and atherosclerosis. For example, the indole derivative varespladib 24 (s-PLA $2 \mathrm{IC}_{50}=15 \mathrm{nM}$, Figure 6) was developed as a treatment for rheumatoid arthritis and atherosclerosis [66-68]. A recent phase II trial showed that oral varespladib was able to reduce progression of atherosclerosis and associated cardiovascular events, without any evidence of adverse effects [67]. In this regard, a novel class of azetidinones represented by SB222657 (25, Lp-PLA IC $_{50}=11.7$ nM, Figure 6) were developed as active site directed Lp-PLA 2 inhibitors [69]. Further studies led to the discovery of a potent Lp-PLA 2 inhibitor SB-435495 possessing a pyrimidinone ring template (26, Lp-PLA $\mathrm{IC}_{50}=0.06 \mathrm{nM}$, Figure 6) by GSK. Lead optimization resulted in the development of darapladib (27, Lp-PLA $\mathrm{IC}_{50}=0.25 \mathrm{nM}$; Figure 6) as a clinical candidate and is the first agent developed as an Lp-PLA $\mathrm{P}_{2}$ inhibitor to treat atherosclerosis and associated cardiovascular diseases [70,71]. Phase II studies of oral darapladib therapy led to reduced Lp-PLA 2 activity in human atherosclerotic plaques in patients with stable coronary heart disease and reduced the levels of inflammatory mediator interleukin-6 [61,72-74]. Currently, darapladib is undergoing phase III trials.

Figure 6. Chemical structures of some representative PLA 2 inhibitors.<smiles>CCc1c(C(=O)C(N)=O)c2c(OCC(=O)OC)cccc2n1Cc1ccccc1</smiles>

Varespladib (24)<smiles>Cn1cc(Cc2cn(CC(=O)N(CCN)Cc3ccc(-c4ccc(C(F)(F)F)cc4)cc3)c(Cc3ccccc3)nc2=O)cn1</smiles>

SB-435495 (26)

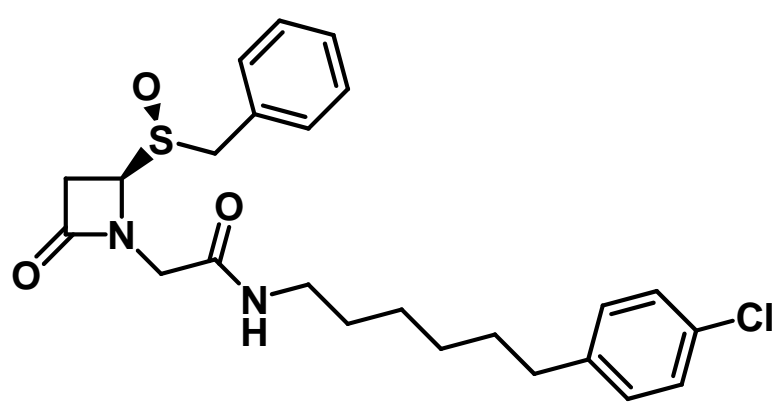

SB-222657 (25)<smiles>CCN(CC)CCN(CCN(Cc1ccc(-c2ccc(F)cc2)cc1)C(=O)OCc1ccccc1)C(=O)Cn1c(SCc2ccc(C(F)(F)F)cc2)nc(=O)c2c1CCC2</smiles>

Darapladib (27)

\section{6. mPGES-1 Inhibitors}

In the prostaglandin biosynthesis pathway, formation of the prostaglandin $\mathrm{E}_{2}\left(\mathrm{PGE}_{2}\right)$, a major mediator of pain and inflammation from prostaglandin $\mathrm{H}_{2}\left(\mathrm{PGH}_{2}\right)$ is catalyzed by $\mathrm{PGE}$ synthases such as cytosolic PGES (cPGES) and microsomal PGE synthases -1 and -2 (mPGES-1 and mPGES-2) [7579]. Furthermore, mPGES-1 is known to transform COX-2 derived endoperoxides. In this regard, the 
membrane associated protein mPGES-1 is an inducible enzyme under inflammatory conditions such as RA, OA and atherosclerosis [77, 78].

Although selective COX-2 inhibitors decrease the formation of proinflammatory $\mathrm{PGE}_{2}$, they exhibit cardiovascular side effects due their suppression of COX-2 derived vasodilatory prostacyclin $\left(\mathrm{PGI}_{2}\right)$ biosynthesis [11,77,78]. Therefore, novel orally active small molecule mPGES-1 inhibitors are considered as an alternative strategy to develop anti-inflammatory agents with superior safety profile. Several ring templates including fatty acid derivatives have been developed as mPGES-1 and dual mPGES-1/5-LOX inhibitors [78].

Merck Frosst reported the development of a number of novel ring templates as potent and selective mPGES-1 inhibitors [80-82]. An indole based agent (28, Figure 7), possessing a COOH group exhibited potent mPGES-1 inhibition (mPGES-1 $\mathrm{IC}_{50}=0.007 \mu \mathrm{M}$ ) and effective PGE $_{2}$ inhibition $\left(\mathrm{IC}_{50}\right.$ $=8.0 \mu \mathrm{M})$ in cell based assays [80]. In another study, a series of phenanthrene imidazole template identified through a high-throughput (HTS) screening was developed as selective mPGES-1 inhibitors with oral activity [81].These agents lack an acidic $(\mathrm{COOH})$ functional group. Compound 29 (Figure 7) was identified as a potent and selective mPGES-1 inhibitor (mPGES-1 $\mathrm{IC}_{50}=0.001 \mu \mathrm{M}$; $\mathrm{PGE}_{2}$ inhibition $\mathrm{IC}_{50}=0.42 \mu \mathrm{M}$ ) with in vivo analgesic activity, although 29 exhibited a short in vivo half life $\left(\mathrm{t}_{1 / 2}=1.5 \mathrm{~h}\right)$ in animal models. In an extension of this work, a disubstituted phenanthrene imidazole (30, Figure 7) containing a propargylic tertiary alcohol moiety was developed that exhibited potent and selective mPGES-1 inhibition (mPGES-1 IC $_{50}=0.001 \mu \mathrm{M}$; mPGES-2 IC $_{50}>30 \mu \mathrm{M}$ ) and oral activity in lipopolysaccharide (LPS)-induced hyperalgesia guinea pig model ( $\mathrm{ED}_{50}=30 \mathrm{mg} / \mathrm{kg}$ ). Interestingly, 30 exhibited a long in vivo pharmacokinetic properties in a rat model $\left(\mathrm{t}_{1 / 2}=20 \mathrm{~h}\right)$ relative to 29 [82].

Recently, pirinixic acid derivatives were developed as a novel class of dual mPGES-1 and 5-LOX enzymes [83]. Among these group of agents 31 (Figure 7), a biphenyl pirinixic acid derivative, possessing a lipophilic $n$-hexyl chain along with a $\mathrm{COOH}$ group exhibited mPGES-1 inhibition (mPGES-1 IC $_{50}=1.3 \mu \mathrm{M}$; 5-LOX IC $_{50}=1.0 \mu \mathrm{M}$ ) along with moderate COX inhibition. It was also reported that enantiomeric forms of these agents exhibit similar activity profile. It should be noted that pirinixic acid ring template was initially reported as a peroxisome proliferator-activated receptor (PPAR- $\alpha$ ) agonist $[84,85]$. Another elegant study developed dual mPGES-1/5-LOX agents based on an arylpyrrolizine ring template present in the anti-inflammatory agent licofelone [86]. The tolylsulfonimide 32 exhibited mPGES-1 inhibition (mPGES-1 IC $_{50}=2.1 \mu \mathrm{M}$ ) and moderate to no inhibition of enzymes COX-1 and COX-2 respectively. In this regard, Proschak and coworkers developed a group of nonacidic mPGES-1 inhibitors based on virtual library screening [87]. These studies identified a biphenyl quinazolinone ring template possessing a benzamide substituent (33), as an mPGES-1 inhibitor $\left(\mathrm{IC}_{50}=0.5 \mu \mathrm{M}\right)$ and did not exhibit COX-1/2 inhibition $\left(\mathrm{IC}_{50}>30 \mu \mathrm{M}\right)$. Furthermore, Pfizer Inc recently reported the development of selective mPGES-1 inhibitors derived from an oxicam ring template. In this regard the biphenyl oxicam derivative 34 (Figure 7), exhibited potent mPGES-1 inhibition (mPGES-1 $\mathrm{IC}_{50}=0.016 \mu \mathrm{M}$ ) and relatively weak COX inhibition (COX-1 $\mathrm{IC}_{50}=118 \mu \mathrm{M}$, COX-2 $\left.\mathrm{IC}_{50}=263 \mu \mathrm{M}\right)$ [88]. 
Figure 7. Chemical structures of some representative PLA 2 inhibitors.<smiles>Cc1c(CC(C)(C)C(=O)O)n(Cc2ccc(Cl)cc2)c2ccc(-c3ccc(-c4ccccc4)c(F)c3)cc12</smiles>

(28)<smiles>N#Cc1cccc(C#N)c1-c1nc2c3ccc(Cl)cc3c3ccccc3c2[nH]1</smiles>

(29)<smiles>CC(C)(O)C#Cc1ccc2c(c1)c1cc(Cl)ccc1c1nc(-c3c(C#N)cccc3C#N)[nH]c21</smiles><smiles>CCCCC(C)(Sc1nc(Cl)cc(NCc2ccc(-c3ccccc3)cc2)n1)C(=O)O</smiles>

(31)<smiles>CCCc1nc2ccc(NC(=O)c3ccccc3Cl)cc2c(=O)n1Cc1ccc(-c2cccc(Cl)c2)cc1</smiles>

(32)<smiles>COc1ccc(S(=O)(=O)NC(=O)CCc2c(-c3ccc(Cl)cc3)c(-c3ccccc3)c3n2CC(C)(C)C3)cc1</smiles><smiles></smiles>

\section{TNF- $\alpha$ Inhibitors}

Treating RA with biological therapeutics that target the proinflammatory cytokine TNF- $\alpha$ has been highly successful. However, their drawback includes high costs, lack of oral activity and adverse events such as autoimmune reactions [19, 89-91]. In this regard several small molecule agents that inhibit TNF- $\alpha$ indirectly have been reported [19, 23]. However, developing an orally active small molecule, that could act as a direct TNF- $\alpha$ inhibitor presents a significant challenge [90]. Toward this 
direction, scientists from Sunesis Pharmaceuticals Inc. developed a small molecule agent that possessed a phenyl indole and a chromone moiety (35, Figure 8). Compound 35 was promoting subunit disassembly of trimeric TNF- $\alpha$ and inhibition in both biochemical (TNF- $\left.\alpha \mathrm{IC}_{50}=22 \mu \mathrm{M}\right)$ and cell (TNF- $\left.\alpha \mathrm{IC}_{50}=4.6 \mu \mathrm{M}\right)$ based assays. In addition, the structure of $\mathbf{3 5}$ in complex with TNF- $\alpha$ dimer was solved [92]. Celgene Corporation recently developed apremilast (36, Figure 8) as an orally active dual phosphodiesterase-4 (PDE4) and TNF- $\alpha$ inhibitor that could be used to treat the autoimmune disorder psoriasis [93]. Compound 36, has a dihydroisoindole ring template and is an $(S)$ enantiomer, whereas the corresponding $(R)$ enantiomer of $\mathbf{3 6}$ was 5 -fold less potent. In an LPS-induced cell based assay, 36 exhibited potent TNF- $\alpha$ inhibition (TNF- $\left.\alpha \mathrm{IC}_{50}=0.077 \mu \mathrm{M}\right)$ and oral activity in animal models $\left(\mathrm{ED}_{50}=0.03 \mathrm{mg} / \mathrm{kg}\right)$. In addition, 36 exhibited potent PDE4 inhibition $\left(\mathrm{PDE} 4 \mathrm{IC}_{50}=\right.$ $0.074 \mu \mathrm{M})$. Recently, Leung and coworkers reported two small molecules structurally similar to natural products. Structure-based design was used to identify small molecule TNF- $\alpha$ inhibitors [94]. Compound $\mathbf{3 7}$ was a quinuclidine derivative and $\mathbf{3 8}$ contained an indoloquinolizidine ring template (Figure 8). Both exhibited TNF- $\alpha$ inhibition (37 TNF- $\alpha \mathrm{IC}_{50}=50 \mu \mathrm{M} ; 38 \mathrm{TNF}-\alpha \mathrm{IC}_{50}=22 \mu \mathrm{M}$ ), although in a cell based assay, $\mathbf{3 8}$ was less potent relative to $\mathbf{3 7}$.

Figure 8. Examples of some representative TNF- $\alpha$ inhibitors.

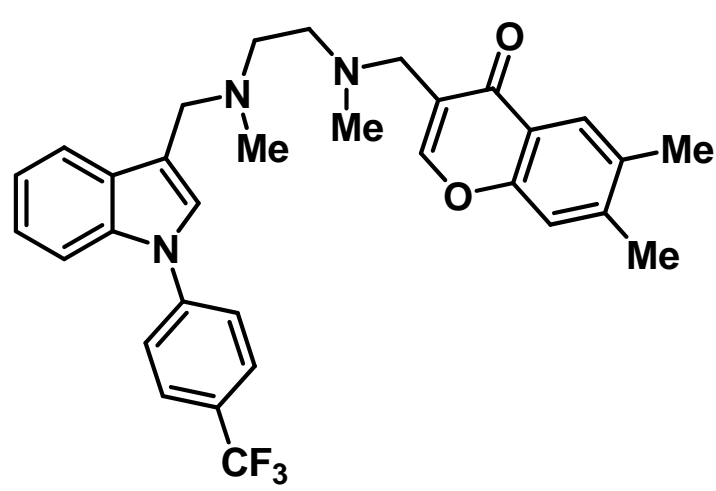

(35)

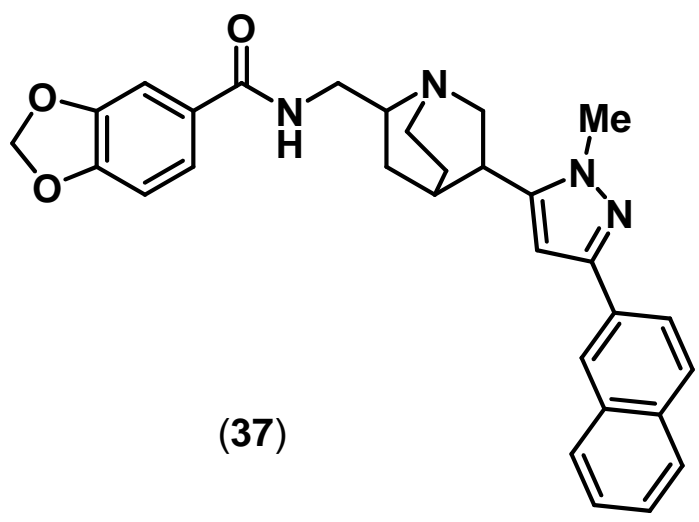<smiles>CCOc1cc([C@H](CS(C)(=O)=O)N2C(=O)c3cccc(NC(C)=O)c3C2=O)ccc1OC</smiles>

Apremilast (36)

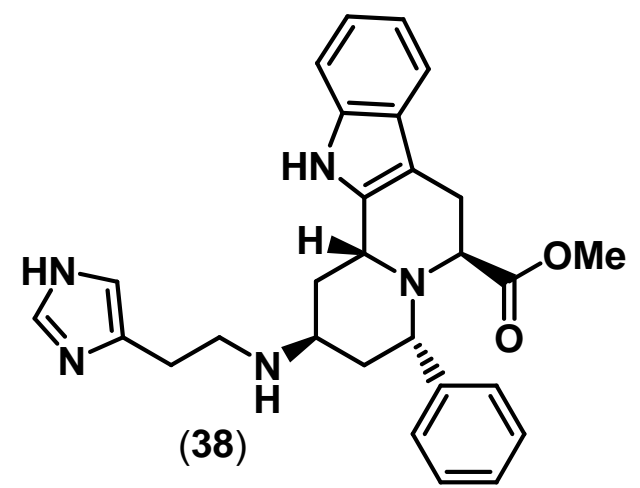

\section{Conclusions}

The story of treating fever, pain and inflammation continues to evolve. Small molecule NSAIDs have dominated the market for over a century. Advances in molecular biology, crystallography and rational drug design approaches have led to the successful identification of novel anti-inflammatory 
targets such as 5-LOX, COX-2, , Lp-PLA 2, mPGES-1 and TNF- $\alpha$, to mention a few. The risks involved in this endeavor, is clearly highlighted by the "coxib" controversy. In an era where new drug pipelines are drying-up and blockbuster agents are facing generic competition, the discovery of novel anti-inflammatory targets continues to propel the development of small molecule therapeutics to treat inflammatory conditions. It is evident that a rational drug discovery effort that combines HTS and fragment screening techniques can provide novel small molecule ring templates that can be optimized by medicinal chemistry methods, to exhibit suitable in vivo activity and optimal pharmacokinetic properties. In spite of the current increase in market share of biological therapeutics to treat inflammatory conditions, small molecule therapeutics continues to dominate the pharmaceutical landscape. The recent advances in deciphering the ability of small molecules to disrupt protein-protein interactions in vivo, provides an exciting opportunity to discover novel small molecule therapeutics to treat inflammation and a wide variety of disease states.

\section{References}

1. Vane, J. R. The fight against rheumatism: From willow bark to COX-1 sparing drugs. J. Physiol. Pharmacol. 2000, 51, 573-586.

2. Marnett, L. J. The COXIB experience: A look in the rearview mirror. Annu. Rev. Pharmacol. Toxicol. 2009, 49, 265-290.

3. Inotai, A.; Hanko, B.; Meszaro, A. Trends in the non-steroidal anti-inflammatory drug market in six central-eastern european countries based on retail information. Pharmacoepidemiol. Drug Saf. 2010, 19, 183-190.

4. Meade, E. A.; Smith, W. L.; DeWitt, D. L. Differential inhibition of prostaglandin endoperoxide synthase (cyclooxygenase) isozymes by aspirin and other non-steroidal anti-inflammatory drugs. J. Biol. Chem. 1993, 268, 6610-6614.

5. Talley, J. J. Selective inhibitors of cyclooxygenase-2 (COX-2). Prog. Med. Chem. Res. 1999, 36, 201-234.

6. Black, W. C. Selective cycloxygenase-2 inhibitors. Annu. Rep. Med. Chem. 2004, 39, 125-138.

7. Penning, T. D.; Talley, J. J.; Bertenshaw, S.R.; Carter, J. S.; Collins, P. W.; Docter, S.; Graneto, M. J.; Lee, L. F.; Malecha, J. W.; Miyashiro, J. M.; Rogers, R. S.; Rogier, D. J.; Yu, S. S.; Anderson, G. D.; Burton, E. G.; Cogburn, J. N.; Gregory, S. A.; Koboldt, C. M.; Perkins, W. E.; Seibert, K.; Veenhuizen, A. W.; Zhang, Y. Y.; Isakson, P. C. Synthesis and biological evaluation of the 1,5-diarylpyrazole class of cyclooxygenase-2 inhibitors: identification of 4-[5-(4methylphenyl)-3-(trifluoromethyl)-1H-pyrazol-1-yl]benzenesulfonamide (SC-58635, celecoxib). J. Med. Chem. 1997, 40, 1347-1365.

8. Prasit, P.; Wang, Z.; Brideau, C.; Chan, C. C.; Charleson, S.; Cromlish, W.; Ethier, D.; Evans, J. F.; Ford-Hutchinson, A. W.; Gauthier, J. Y.; Gordon, R.; Guay, J.; Gresser, M.; Kargman, S.; Kennedy, B.; Leblanc, Y.; Léger, S.; Mancini, J.; O'Neill, G. P.; Ouellet, M.; Percival, M. D.; Perrier, H.; Riendeau, D.; Rodger, I.; Zamboni, R. The discovery of rofecoxib, [MK 966, Vioxx, 4-(4'-methylsulfonylphenyl)-3-phenyl-2(5H)-furanone], an orally active cyclooxygenase-2inhibitor. Bioorg. Med. Chem. Lett. 1999, 9, 1773-1778. 
9. Luong, C.; Miller, A.; Barnett, J.; Chow, J.; Ramesha, C.; Browner, M. F. Flexibility of the NSAID binding site in the structure of human cyclooxygenase-2. Nat. Struct. Biol. 1996, 3, 927-933.

10. Kurumbail, R. G.; Stevens, A. M.; Gierse, J. K.; McDonald, J. J.; Stegeman, R. A.; Pak, J. Y.; Gildehaus, D.; Miyashiro, J. M.; Penning, T. D.; Seibert, K.; Isakson, P. C.; Stallings, W. C. Structural basis for selective inhibition of cyclooxygenase- 2 by anti-inflammatory agents. Nature 1996, 384, 644-648.

11. Mitchell, J. A.; Warner, T. D. COX isoforms in the cardiovascular system: Understanding the activities of non-steroidal anti-inflammatory drugs. Nat. Rev. Drug Discov. 2006, 5, 75-85.

12. Zhang, J. J.; Ding, E. L.; Song, Y. Q. Adverse effects of cyclooxygenase 2 inhibitors on renal and arrhythmia events-meta-analysis of randomized trials. JAMA 2006, 296, 1619-1632.

13. Smith, T. J. Cyclooxygenases as the principle target for the action of NSAIDs. Rheum. Clinics N. Amer. 1998, 24, 501-523.

14. Fourie, A. M. Modulation of inflammatory disease by inhibitors of leukotriene A4 hydrolase. Curr. Opin. Investig. Drugs 2009, 10, 1173-1182.

15. Charlier, C.; Michaux, C. Dual inhibition of cyclooxygenase-2 (COX-2) and 5-lipoxygenase (5LOX) as a new strategy to provide safer nonsteroidal anti-inflammatory drugs. Eur. J. Med. Chem. 2003, 38, 645-659.

16. Poeckel, D.; Funk, C. D. The 5-lipoxygenase/leukotriene pathway in preclinical models of cardiovascular disease. Cardiovasc. Res. 2010, 86, 243-253.

17. Wang, D.; Dubois, R. N. Prostaglandins and cancer. Gut 2006, 55, 115-122.

18. Cha, Y. I.; Dubois, R. N. NSAIDs and cancer prevention: targets downstream of COX-2. Annu. Rev. Med. 2007, 58, 239-252.

19. Palladino, M. A.; Bahjat, F. R.; Theodorakis, E. A.; Moldaver, L. L. Anti-TNF- $\alpha$ therapies: The next generation. Nat. Rev. Drug Disc. 2003, 2, 736-746.

20. Seruga, B.; Zhang, H.; Bernstein, L. J.; Tannock, I. F. Cytokines and their relationship to the symptoms and outcome of cancer. Nat. Rev. Cancer 2008, 8, 887-899.

21. Craft, J. M.; Watterson, D. M.; Van Eldik, L. J. Neuroinflammation: A potential therapeutic target. Expert Opin. Ther. Targets 2005, 9, 887-900.

22. Muller, N. COX-2 inhibitors as antidepressants and antipsychotics: Clinical evidence. Curr. Opin. Invest. Drugs 2010, 11, 31-42.

23. Rainsford, K. D. Anti-inflammatory drugs in the 21st century. Subcell. Biochem. 2007, 42, 3-27.

24. Wallace, J. L.; Ignarro, L. J.; Fiorucci, S. Potential cardioprotective actions of NO-releasing aspirin. Nat. Rev. Drug Discov. 2002, 1, 375-382.

25. Bernstein, P. Chemistry and structure-activity relationships of leukotriene receptor antagonists. Am. J. Respir. Crit. Care Med. 1998, 157, S220-S226.

26. Ruschitzka, F. T.; Wenger, R. H.; Stallmach, T.; Quaschning, T.; de Wit, C.; Wagner, K.; Labugger, R.; Kelm, M.; Noll, G.; Rülicke, T.; Shaw, S.; Lindberg, R. L.; Rodenwaldt, B.; Lutz, H.; Bauer, C.; Lüscher, T. F.; Gassmann, M. Nitric oxide prevents cardiovascular disease and determines survival in polyglobulic mice overexpressing erythropoietin. Proc. Natl. Acad. Sci. USA 2000, 97, 11609-11613. 
27. Muscara, M. N.; McNight, W.; Del Soldato, P.; Wallace, J. L. Effects of a nitric oxide-releasing naproxen derivative on hypertension and gastric damage induced by chronic nitric oxide inhibition in the rat. Pharmacol. Lett. 1998, 62, 235-240.

28. Bandarage, U. K.; Chen, L.; Fang, X.; Garvey, D. S.; Glavin, A.; Janero, D. R.; Letts, L. G.; Mercer, G. J.; Saha, J. K.; Schroeder, J. D.; Shumway, M. J.; Tam, S. W. Nitrosothiol esters of diclofenac: Synthesis and pharmacological characterization as gastrointestinal-sparing prodrugs. J. Med. Chem. 2000, 43, 4005-4016.

29. Fitzhugh, A. L.; Keefer, L. K. Diazeniumdiolates: pro- and antioxidant applications of the NONOates. Free Radic. Biol. Med. 2000, 28, 1463-1469.

30. Velázquez, C. A.; Rao, P. N. P.; Knaus, E. E. Novel nonsteroidal antiinflammatory drugs possessing a nitric oxide donor diazen-1-ium-1,2-diolate moiety: design, synthesis, biological evaluation, and nitric oxide release studies. J. Med. Chem. 2005, 48, 4061-4067.

31. Velázquez, C. A.; Chen, Q. H.; Citro, M. L.; Keefer, L. K.; Knaus, E. E. Second-generation aspirin and indomethacin prodrugs possessing an O2-(acetoxymethyl)-1-(2-carboxypyrrolidin-1yl)diazenium-1,2-diolate nitric oxide donor moiety: Design, synthesis, biological evaluation, and nitric oxide release studies. J. Med. Chem. 2008, 51, 1954-1961.

32. Chegaev, K.; Lazzarato, L.; Tosco, P.; Cena, C.; Marini, E.; Rolando, B.; Carrupt, P. A.; Fruttero, R.; Gasco, A. NO-donor COX-2 inhibitors: New nitrooxy-substituted 1,5-diarylimidazoles endowed with COX-2 inhibitory and vasodilator properties. J. Med. Chem. 2007, 50, 1449-1457.

33. Wey, S. J.; Augustyniak, M. E.; Cochran, E. D.; Ellis, J. L.; Fang, X.; Garvey, D. S.;. Janero, D. R.; Letts, L. G.; Martino, A. M.; Melim, T. L.; Murty, M. G.; Richardson, S. K.; Schroeder, J. D.; Selig, W. M.; Trocha, A. M.; Wexler, R. S.; Young, D. V.. Zemtseva, I. S.; Zifcak, B. M. Structure-based design, synthesis, and biological evaluation of indomethacin derivatives as cyclooxygenase-2 inhibiting nitric oxide donors. J. Med. Chem. 2007, 50, 6367-6382.

34. Lazzarato, L.; Donnola, M.; Rolando, B.; Marini, E.; Cena, C.; Coruzzi, G.; Guaita, E.; Morini, G.; Fruttero, R.; Gasco, A.; Biondi, S. Searching for new NO-donor aspirin-like molecules: A new class of nitrooxy-acyl derivatives of salicylic acid. J. Med. Chem. 2008, 51, 1894-1903.

35. Moriarty, L. M.; Lally, M. N.; Carolan, C. G.; Jones, M.; Clancy, J. M.; Gilmer, J. F. Discovery of a true aspirin prodrug. J. Med. Chem. 2008, 51, 7991-7999.

36. Lazzarato, L.; Donnola, M.; Rolando, B.; Chegaev, K.; Marini, E.; Cena, C.; Di Stilo, A.; Fruttero, R.; Biondi, S.; Ongini, E.; Gasco, A. (Nitrooxyacyloxy)methyl esters of aspirin as novel nitric oxide releasing aspirins. J. Med. Chem. 2009, 52, 5058-5068.

37. Rao, P. N. P.; Rajesh, K. G. Apricoxib, a COX-2 inhibitor for the potential treatment of pain and cancer. IDrugs 2009, 12, 711-722.

38. Biava, M.; Porretta, G. C.; Poce, G.; Supino, S.; Forli, S.; Rovini, M.; Cappelli, A.; Manetti, F.; Botta, M.; Sautebin, L.; Rossi, A.; Pergola, C.; Ghelardini, C.; Vivoli, E.; Makovec, F.; Anzellotti, P.; Patrignani, P.; Anzini, M. Cyclooxygenase-2 inhibitors. 1,5-diarylpyrrol-3-acetic esters with enhanced inhibitory activity toward cyclooxygenase-2 and improved cyclooxygenase2/cyclooxygenase-1 selectivity. J. Med. Chem. 2007, 50, 5403-5411.

39. Anzini, M.; Rovini, M.; Cappelli, A.; Vomero, S.; Manetti, F.; Botta, M.; Sautebin, L.; Rossi, A.; Pergola, C.; Ghelardini, C.; Norcini, M.; Giordani, A.; Makovec, F.; Anzellotti, P.; Patrignani, P.; Biava, M. Synthesis, biological evaluation, and enzyme docking simulations of 1,5-diarylpyrrole- 
3-alkoxyethyl ethers as selective cyclooxygenase-2 inhibitors endowed with anti-inflammatory and antinociceptive activity. J. Med. Chem. 2008, 51, 4476-4481.

40. Biava, M.; Porretta, G. C.; Poce, G.; Battilocchio, C.; Manetti, F.; Botta, M.; Forli, S.; Sautebin, L.; Rossi, A.; Pergola, C.; Ghelardini, C.; Galeotti, N.; Makovec, F.; Giordani, A.; Anzellotti, P.; Patrignani, P.; Anzini, M. Novel ester and acid derivatives of the 1,5-diarylpyrrole scaffold as anti-inflammatory and analgesic agents: Synthesis and in vitro and in vivo biological evaluation. $J$. Med. Chem. 2010, 53, 723-733.

41. Gierse, J.; Nickols, M.; Leahy, K.; Warner, J.; Zhang, Y.; Cortes-Burgos, L.; Carter, J.; Seibert, K.; Masferrer, J. Evaluation of COX-1/COX-2 selectivity and potency of a new class of COX-2 inhibitors. Eur. J. Pharmacol. 2008, 588, 93-98.

42. Renard, J. F.; Arslan, D.; Garbacki, N.; Pirotte, B.; de Leval, X. Pyridine analogues of nimesulide: design, synthesis, and in vitro and in vivo pharmacological evaluation as promising cyclooxygenase 1 and 2 inhibitors. J. Med. Chem. 2009, 52, 5864-5871.

43. Swarbrick, M. E.; Beswick, P. J.; Gleave, R. J.; Green, R. H.; Bingham, S.; Bountra, C.; Carter, M. C.; Chambers, L. J.; Chessell, I. P.; Clayton, N. M.; Collins, S. D.; Corfield, J. A.; Hartley, C. D.; Kleanthous, S.; Lambeth, P. F.; Lucas, F. S.; Mathews, N.; Naylor, A.; Page, L. W.; Payne, J. J.; Pegg, N. A.; Price, H. S.; Skidmore, J.; Stevens, A. J.; Stocker, R.; Stratton, S. C.; Stuart, A. J.; Wiseman, J. O. Identification of [4-[4-(methylsulfonyl)phenyl]-6-(trifluoromethyl)-2-pyrimidinyl] amines and ethers as potent and selective cyclooxygenase-2 inhibitors. Bioorg. Med. Chem. Lett. 2009, 19, 4504-4508.

44. Beswick, P. J.; Blackaby, A. P.; Bountra, C.; Brown, T.; Browning, K.; Campbell, I. B.; Corfield, J.; Gleave, R. J.; Guntrip, S. B.; Hall, R. M.; Hindley, S.; Lambeth, P. F.; Lucas, F.; Mathews, N.; Naylor, A.; Player, H.; Price, H. S.; Sidebottom, P. J.; Taylor, N. L.; Webb, G.; Wiseman, J. Identification and optimisation of a novel series of pyrimidine based cyclooxygenase-2 (COX-2) inhibitors. Utilisation of a biotransformation approach. Bioorg. Med. Chem. Lett. 2009, 19, 4509-4514.

45. Ramalho, T. C.; Rocha, M. V. J.; Da Cunna, E. F. F.; Freitas, M. P. The search for new COX-2 inhibitors: A review of 2002-2008 patents. Expert Opin. Ther. Patents 2009, 19, 1193-1228.

46. Reddy, M. V. R.; Billa, V. K.; Pallela, V. R.; Mallireddigari, M. R.; Boominathan, R.; Gabriel, J. L.; Reddy, E. P. Design, synthesis, and biological evaluation of 1-(4-sulfamylphenyl)-3trifluoromethyl-5-indolyl pyrazolines as cyclooxygenase-2 (COX-2) and lipoxygenase (LOX) inhibitors. Bioorg. Med. Chem. 2008, 16, 3907-3916.

47. Geronikaki, A. A.; Lagunin, A. A.; Hadjipavlou-Litina, D. I.; Eleftheriou, P. T.; Filimonov, D. A.; Poroikov, V. V.; Alam, I.; Saxena, A. K. Computer-aided discovery of anti-inflammatory thiazolidinones with dual cyclooxygenase/lipoxygenase inhibition. J. Med. Chem. 2008, $51,1601-1609$.

48. Dailey, L A.; Imming, P. 12-Lipoxygenase: Classification, possible therapeutic benefits from inhibition and inhibitors. Curr. Med. Chem. 1999, 6, 389-398.

49. Chowdhury, M. A.; Abdellatif, K. R.; Dong, Y.; Das, D.; Yu, G.; Velázquez, C. A.; Suresh, M. R.; Knaus, E. E. Synthesis and biological evaluation of salicylic acid and N-acetyl-2carboxybenzenesulfonamide regioisomers possessing a N-difluoromethyl-1,2-dihydropyrid-2-one 
pharmacophore: dual inhibitors of cyclooxygenases and 5-lipoxygenase with anti-inflammatory activity. Bioorg. Med. Chem. 2009, 19, 6855-6861.

50. Chowdhury, M. A.; Abdellatif, K. R.; Dong, Y.; Das, D.; Suresh, M. R.; Knaus, E. E. Synthesis of celecoxib analogues possessing a N-difluoromethyl-1,2-dihydropyrid-2-one 5-lipoxygenase pharmacophore: Biological evaluation as dual inhibitors of cyclooxygenases and 5-lipoxygenase with anti-inflammatory activity. J. Med. Chem. 2009, 52, 1525-1529.

51. Yu. G.; Chowdhury, M. A.; Abdellatif, K. R.; Dong, Y.; Rao, P. N. P.; Das, D.; Velázquez, C. A.; Suresh, M. R.; Knaus, E. E. Phenylacetic acid regioisomers possessing a N-difluoromethyl-1,2dihydropyrid-2-one pharmacophore: Evaluation as dual inhibitors of cyclooxygenases and 5lipoxygenase with anti-inflammatory activity. Bioorg. Med. Chem. 2010, 20, 896-902.

52. Chen, C. S.; Tan, C. M.; Huang, C. H.; Chang, L. C.; Wang, J. P.; Cheng, F. C.; Chern, J. W. Discovery of 3-(4-bromophenyl)-6-nitrobenzo[1.3.2]dithiazolium ylide 1,1-dioxide as a novel dual cyclooxygenase/5-lipoxygenase inhibitor that also inhibits tumor necrosis factor-alpha production. Bioorg. Med. Chem. 2010, 18, 597-604.

53. Balsinde, J.; Balboa, M. A.; Insel, P. A.; Dennis, E. A. Regulation and inhibition of phospholipase A . Annu. Rev. Pharmacol. Toxicol. 1999, 39, 175-189.

54. Blank, M. L.; Lee, T.; Fitzgerald, V.; Snyder, F. A specific acetylhydrolase for 1-alkyl-2-acetylsn-glycero-3-phosphocholine (a hypotensive and platelet-activating lipid). J. Biol. Chem. 1981, 256, 175-178.

55. Berliner, J. A.; Subbanagounder, G.; Leitinger, N.; Watson, A.D.; Vora, D. Evidence for a role of phospholipid oxidation products in atherogenesis. Trends Cardiovasc. Med. 2001, 11, 142-147.

56. Tjoelker, L. W.; Eberhardt, C.; Unger, J.; Trong, H. L.; Zimmerman, G. A.; McIntyre, T. M.; Stafforini, D. M.; Prescott, S. M.; Gray, P. W. Plasma platelet-activating factor acetylhydrolase is a secreted phospholipase $\mathrm{A}_{2}$ with a catalytic triad. J. Biol. Chem. 1995, 270, 25481-25487.

57. Macphee, C. H.; Nelson, J.; Zalewski, A. Role of lipoprotein-associated phospholipase $A_{2}$ in atherosclerosis and its potential as a therapeutic target. Curr. Opin. Pharmacol. 2006, 6, 154-161.

58. Tjoelker, L. W.; Wilder, C.; Eberhardt, C.; Stafforini, D. M.; Dietsch, G.; Schimpf, B.; Hooper, S.; Le Trong, H.; Cousens, L. S.; Zimmerman, G. A.; Yamadat, Y.; McIntyre, T. M.; Prescot, S. M.; Gray, P. W. Anti-inflammatory properties of a platelet-activating factor acetylhydrolase. Nature 1995, 374, 549-553.

59. Tellis, C. C.; Tselepsis, A. D. The role of lipoprotein-associated phospholipase $\mathrm{A}_{2}$ in atherosclerosis may depend on its lipoprotein carrier in plasma. Biochim. Biophys. Acta 2009, 1791, 327-338.

60. Caslake, M. J.; Packard, C. J. Lipoprotein-associated phospholipase $A_{2}$ as a biomarker for coronary disease and stroke. Nat. Rev. Cardiol. 2005, 2, 529-535.

61. Wilensky, R. L.; Shi, Y.; Mohler, E. R.; Hamamdzic, D.; Burgert, M. E.; Li, J.; Postle, A.; Fenning, R. S.; Bollinger, J. G.; Hoffman, B. E.; Pelchovitz, D. J.; Yang, J.; Mirabile, R. C.; Webb, C. L.; Zhang, L.; Zhang, P.; Gelb, M. H.; Walker, M. C.; Zalewski, A.; Macphee, C. H. Inhibition of lipoprotein-associated phospholipase $\mathrm{A}_{2}$ reduces complex coronary atherosclerotic plaque development. Nat. Med. 2008, 14, 1059-1066. 
62. Zalewski, A.; Nelson, J. J.; Hegg, L.; Macphee, C. Role of lipoprotein-associated phospholipase $\mathrm{A}_{2}$ in atherosclerosis: Biology, epidemiology, and possible therapeutic target. Arterioscler. Thromb. Vasc. Biol. 2005, 25, 923-931.

63. Shi, Y.; Zhang, P.; Zhang, L.; Osman, H.; Mohler, E. R.; Macpheec, C.; Zalewski, A.; Postle, A.; Wilensky, R. L. Role of lipoprotein-associated phospholipase $A_{2}$ in leukocyte activation and inflammatory responses. Atherosclerosis 2007, 191, 54-62.

64. Zalewski, A.; Nelson, J. J.; Heg, J. J. Macphee, C. Lp-PLA 2 : A new kid on the block. Clin. Chem. 2006, 52, 1645-1649.

65. Lee, K. L.; Foley, M. A.; Chen, L.; Behnke, M. L.; Lovering, F. E.; Kirincich, S. J.; Wang, W.; Shim, J.; Tam, S.; Shen, M. W.; Khor, S.; Xu, X.; Goodwin, D. G.; Ramarao, M. K.; NickersonNutter, C.; Donahue, F.; Ku, M. S.; Clark, J. D.; McKew, J. C. Discovery of ecopladib, an indole inhibitor of cytosolic phospholipase $\mathrm{A}_{2} \alpha$. J. Med. Chem. 2007, 50, 1380-1400.

66. Suckling, K. E. Phospholipase $\mathrm{A}_{2}$ inhibitors in the treatment of atherosclerosis: A new approach moves forward in the clinic. Expert Opin. Investig. Drugs. 2009, 18, 1425-1430.

67. Rosenson, R. S.; Hislop, C.; McConnell, D.; Elliott, M.; Stasiv, Y.; Wang, N., Waters, D. D. Effects of 1-H-indole-3-glyoxamide (A-002) on concentration of secretory phospholipase $\mathrm{A}_{2}$ (PLASMA study): A phase II double-blind, randomized, placebo-controlled trial. Lancet 2009, 373, 649-658.

68. Corson, M. A.; Phospholipase $\mathrm{A}_{2}$ inhibitors in atherosclerosis: The race is on. Lancet 2009, 373, 608-610.

69. Tew, D. G.; Boyd, H. F.; Ashman, S.; Theobald, C.; Leach, C. A. Mechanism of inhibition of LDL phospholipase $\mathrm{A}_{2}$ by monocyclic beta-lactams: Burst kinetics and the effect of stereochemistry. Biochemistry 1998, 37, 10087-10093.

70. Blackie, J. A.; Bloomer, J. C.; Brown, M. J.; Cheng, H. Y.; Hammond, B.; Hickey, D. M.; Ife, R. J.; Leach, C. A.; Lewis, V. A.; Macphee, C. H.; Milliner, K. J.; Moores, K. E.; Pinto, I. L.; Smith, S. A.; Stansfield, I. G.; Stanway, S. J.; Taylor, M. A.; Theobald, C. J. The identification of clinical candidate SB-480848: A potent inhibitor of lipoprotein-associated phospholipase $\mathrm{A}_{2}$. Bioorg. Med. Chem. Lett. 2003, 13, 1067-1070.

71. Leach, C. A.; Smith, S. A. N-Substituted pyridinone and pyrimidinone derivatives for use as Lp$\mathrm{PLA}_{2}$ inhibitors in the treatment atherosclerosis. World Patent 2003, WO 03/086400, 1-33.

72. Mohler, E. R.; Ballantyne, C. M.; Davidson, M. H.; Hanefeld, M.; Ruilope, L. M.; Johnson, J. L.; Zalewski, A. The effect of darapladib on plasma lipoprotein-associated phospholipase $\mathrm{A}_{2}$ activity and cardiovascular biomarkers in patients with stable coronary heart disease or coronary heart disease risk equivalent: The results of a multicenter, randomized, double-blind, placebo-controlled study. J. Am. Coll. Cardiol. 2008, 51, 1632-1641.

73. Rosenson, R. S. Future role for selective phospholipase $A_{2}$ inhibitors in the prevention of atherosclerotic cardiovascular disease. Cardiovasc. Drugs Ther. 2009, 23, 93-101.

74. McCullough, P. A. Darapladib and atherosclerotic plaque: Should lipoprotein-associated phospholipase $\mathrm{A}_{2}$ be a therapeutic target? Curr. Atherosclerosis Rep. 2009, 11, 334-337.

75. Jakobsson, P. J.; Morgenstern, R.; Mancini, J.; Ford-Hutchinson, A.; Persson, B. Common structural features of MAPEG-A widespread superfamily of membrane associated proteins with 
highly divergent functions in eicosanoid and glutathione metabolism. Protein Sci. 1999, $8,689-692$.

76. Jakobsson, P. J.; Thore'n, S.; Morgenstern, R. Samuelsson B. Identification of human prostaglandin E synthase: A microsomal, glutathione-dependent, inducible enzyme, constituting a potential novel drug target. Proc. Natl. Acad. Sci. USA 1999, 96, 7220-7225.

77. Samuelsson, B.; Morgenstern, R.; Jakobsson, P. J. Membrane prostaglandin E synthase-1: A novel therapeutic target. Pharmacol. Rev. 2007, 59, 207-224.

78. Friesen, R. W.; Mancini, J. A. Microsomal prostaglandin $E_{2}$ synthase-1 (mPGES-1): A novel antiinflammatory therapeutic target. J. Med. Chem. 2008, 51, 4059-4067.

79. Jegerschoeld, C.; Pawelzik, S.-C.; Purhonen, P.; Bhakat, P.; Gheorghe, K. R.; Gyobu, N.; Mitsuoka, K.; Morgenstern, R.; Jakobsson, P. J.; Hebert, H. Structural basis for induced formation of the inflammatory mediator prostaglandin E2. Proc. Natl. Acad. Sci. USA 2009, $105,11110-11115$.

80. Riendeau, D.; Aspiotis, R.; Ethier, D.; Gareau, Y.; Grimm, E. L.; Guay, J.; Guiral, S.; Juteau, H.; Mancini, J. A.; Méthot, N.; Rubin, J.; Friesen, R. W. Inhibitors of the inducible microsomal prostaglandin E2 synthase (mPGES-1) derived from MK-886. Bioorg. Med. Chem. Lett. 2005, $15,3352-3355$.

81. Côté, B.; Boulet, L.; Brideau, C.; Claveau, D.; Ethier, D.; Frenette, R.; Gagnon, M.; Giroux, A.; Guay, J.; Guiral, S.; Mancini, J.; Martins, E.; Massé, F.; Méthot, N.; Riendeau, D.; Rubin, J.; Xu, D.; Yu, H.; Ducharme, Y.; Friesen, R. W. Substituted phenanthrene imidazoles as potent, selective, and orally active mPGES-1 inhibitors. Bioorg. Med. Chem. Lett. 2007, 17, 6816-6820.

82. Giroux, A.; Boulet, L.; Brideau, C.; Chau, A.; Claveau, D.; Côté, B.; Ethier, D.; Frenette, R.; Gagnon, M.; Guay, J.; Guiral, S.; Mancini, J.; Martins, E.; Massé, F.; Méthot, N.; Riendeau, D.; Rubin, J.; Xu, D.; Yu, H.; Ducharme, Y.; Friesen, R. W. Discovery of disubstituted phenanthrene imidazoles as potent, selective and orally active mPGES-1 inhibitors. Bioorg. Med. Chem. Lett. 2009, 19, 5837-5841.

83. Koeberle, A.; Zettl, H.; Greiner, C.; Wurglics, M.; Schubert-Zsilavecz, M.; Werz, O. Pirinixic acid derivatives as novel dual inhibitors of microsomal prostaglandin E2 synthase-1 and 5lipoxygenase. J. Med. Chem. 2008, 51, 8068-8076.

84. Issemann, I.; Green, S. Activation of a member of the steroid hormone receptor superfamily by peroxisome proliferators. Nature 1990, 347, 645-650.

85. Keller, H.; Devchand, P. R.; Perroud, M.; Wahli, W. PPAR alpha structure-function relationships derived from species-specific differences in responsiveness to hypolipidemic agents. Biol. Chem. 1997, 378, 651-655.

86. Liedtke, A. J.; Keck, P. R.; Lehmann, F.; Koeberle, A.; Werz, O.; Laufer, S. A. Arylpyrrolizines as inhibitors of microsomal prostaglandin E2 synthase-1 (mPGES-1) or as dual inhibitors of mPGES-1 and 5-lipoxygenase (5-LOX). J. Med. Chem. 2009, 52, 4968-4972.

87. Rörsch, F.; Wobst, I.; Zettl, H.; Schubert-Zsilavecz, M.; Grösch, S.; Geisslinger, G.; Schneider, G.; Proschak, E. Nonacidic inhibitors of human microsomal prostaglandin synthase 1 (mPGES 1) identified by a multistep virtual screening protocol. J. Med. Chem. 2010, 53, 911-915. 
88. Wang, J.; Limburg, D.; Carter, J.; Mbalaviele, G.; Gierse, J.; Vazquez, M. Selective inducible microsomal prostaglandin E(2) synthase-1 (mPGES-1) inhibitors derived from an oxicam template. Bioorg. Med. Chem. Lett. 2010, 20, 1604-1609.

89. Foxwell, B.; Andreakos, E.; Brennan, F.; Feldmann, M.; Smith, C.; Conron, M. Prospects for the development of small molecular weight compounds to replace anti-tumour necrosis factor biological agents. Ann. Rheum. Dis. 2003, 62, ii90-ii93.

90. Wells, J. A.; McClendon, C. L. Reaching for high-hanging fruit in drug discovery at proteinprotein interfaces. Nature 2007, 450, 1001-1009.

91. Taylor, P. C. The future of TNF- $\alpha$ antagonism. Future Rheumatol. 2007, 2, 233-236.

92. He, M. M.; Smith, A. S.; Oslob, J. D.; Flanagan, W. M.; Braisted, A. C.; Whitty, A.; Cancilla, M. T.; Wang, J.; Lugovskoy, A. A.; Yoburn, J. C.; Fung, A. D.; Farrington, G.; Eldredge, J. K.; Day, E. S.; Cruz, L. A.; Cachero, T. G.; Miller, S. K.; Friedman, J. E.; Choong, I. C.; Cunningham, B. C. Small-molecule inhibition of TNF-alpha. Science 2005, 310, 1022-1025.

93. Man, H. W.; Schafer, P.; Wong, L. M.; Patterson, R. T.; Corral, L. G.; Raymon, H.; Blease, K.; Leisten, J.; Shirley, M. A.; Tang, Y.; Babusis, D. M.; Chen, R.; Stirling, D.; Muller, G. W. Discovery of (S)-N-[2-[1-(3-ethoxy-4-methoxyphenyl)-2-methanesulfonylethyl]-1,3-dioxo-2,3dihydro-1H-isoindol-4-yl] acetamide (apremilast), a potent and orally active phosphodiesterase 4 and tumor necrosis factor-alpha inhibitor. J. Med. Chem. 2009, 52, 1522-1524.

94. Chan, D. S.; Lee, H. M.; Yang, F.; Che, C. M.; Wong, C. C. L.; Abagyan, R.; Leung, C. H.; Ma, D. L. Structure-based discovery of natural-product-like TNF- $\alpha$ inhibitors. Angew. Chem. Int. Ed. 2010, 49, 2860-2864.

(C) 2010 by the authors; licensee MDPI, Basel, Switzerland. This article is an Open Access article distributed under the terms and conditions of the Creative Commons Attribution license (http://creativecommons.org/licenses/by/3.0/). 